\title{
HISTORICAL DISSERTATIONS DEFENDED IN 2004
}

Jurgita Verbickienė (University of Vilnius). Žydai Lietuvos Didžiosios Kunigaikštystès visuomeneje: sugyvenimo aspektai [Jews in the Society of the Grand Duchy of Lithuania: Aspects of Coexistence].

The object of this dissertation is the history of Jews as a part of society in the Grand Duchy of Lithuania and their interaction with Christian society. Both published and unpublished sources were used. The author sought to describe the Jewish community, its structure, size and distribution; to examine the context of the Jews' legal and social position within the state as well as the general charters regulating their status; to single out the epicentres of conflicts between Jews and the rest of townsfolk; to reconstruct the attitudes of gentile society towards the Jews within the Grand Duchy of Lithuania, and the factors that formed them; and to assess the conduct of Jews and their attitude towards society at large in the Grand Duchy of Lithuania.

The author concluded that a social formation of non-Christians existed alongside the class structure of the Grand Duchy. She stressed that the ways of controlling the distribution of the Jews discovered in the cities in pursuit of smooth coexistence proved to be ineffective: it was impossible to squeeze the Jews into a narrow quarter. Her research showed that in most cities of the Grand Duchy a policy of coexistence with the Jews was accompanied by strong constraints on their economic activity.

Liudas Jovaiša (University of Vilnius). Katalikiškoji reforma Žemaičiu vyskupijoje. [Catholic Reform in the Diocese of Žemaitija].

The author of this dissertation chose to shed the light on the unexplored process of the Catholic Reformation within the Grand Duchy of Lithuania. He endeavoured to trace changes in religious life during the Counter-Reformation and to determine the significance of Catholic reforms. A case study of the Diocese of Žemaitija (1576-1649) was used to achieve the tasks as follows: to examine the activities of Žemaitian bishops and to establish the value of their role in reforming the Diocese; to reveal the tendencies of disciplinary reform of the Catholic clergy and to display subsequent changes; to describe reforms in clerical training and education; to detect changes in priests' self-identity as well as changes in prestige of ecclesiastical offices; to investigate the organisation of 
parishes and missionary pastoral care; to single out the main tendencies within Catholic reforms concerning parish pastoral care; to investigate religious life and to identify the type of spirituality of the Catholic Reformation; to analyse the activities of the regular clergy and to show their influence over the progress of reform; to ascertain the place of the laity in the Catholic Reformation; and to establish the influence of the Catholic Reformation on the development of Lithuanian society in general.

The research period embraces the activities of six Žemaitian bishops, all of whom were devoted to carrying out reforms. They summoned diocesan synods, carried out visits ad limina, changed the structure of deaneries, looked after the functioning of the diocesan seminary, supported the editions of elementary religious literature in Lithuanian, fostered the activity of religious orders, stimulated the spiritual life of the laity and contributed to the well-being of the Church by their donations. A type of parish priest developed who was distant from the laity in his way of life, but close to his parishioners in his origin and language. Collective spiritual formation with the compulsory minimum of knowledge was introduced into the training of clergy. As a result of the reform the pastoral duty of a priest as a shepherd was greatly emphasised. During the first half of the seventeenth century almost all parish churches previously lost to the Protestants were regained. Sacramental practice was the core of religious life in the age of the Catholic Reformation. Special attention to works of charity reduced tensions within society.

Agnius Urbanavičius (Lithuanian Institute of History, Vytautas Magnus University). Vilniaus naujieji miestiečiai 1663-1795 m. [New Citizens of Vilnius 1663-1795].

The chosen object of the dissertation is the admission to the rights of urban citizenship in early modern Vilnius and the changes in the number and composition of the new citizens of Vilnius in the course of time. Research was based on the administrative records of the new citizens, drafted by Vilnius city council. A large number of sources is employed in research for the first time. The author seeks to find out what the conditions of admission to the rights of urban citizenship in Vilnius were; to estimate how many persons became new citizens of Vilnius in the course of time and find out whether their number fluctuated; to discover how many occupations were shared by the new citizens of Vilnius and how many individuals of certain occupations (the most numerous ones) became new citizens of Vilnius in certain periods; to reveal the geography of the origin of new citizens: in what countries and administrative divisions (i.e. palatinates - only within the Grand Duchy of Lithuania) the new citizens were born and how many of them (regarding their geographical origin) became new citizens in certain periods; to explore 
their social origin (e.g. did they come from a city, small town or village?) and how many of them (relating to their social origin) became new citizens in a certain period.

In the period between 1663 and 1795, new citizens of Vilnius were mostly newcomers $(93,8 \%)$, usually professionally educated merchants and artisans (sometimes dealers and journeymen), who became citizens of Vilnius after satisfying set requirements and swearing allegiance to the authorities of the city of Vilnius and the ruler of the state. The new citizens complemented the community of Vilnius citizens not only demographically, but also both with the experience of professional activity and cultural experience, brought from nearly all over Europe and from some Asian countries.

Aistė Lazauskienè (Vytautas Magnus University, Lithuanian Institute of History). Lietuvos savivaldybes 1918-1920 $\mathrm{m}$. [The Municipalities of Lithuania, 1918-1920].

The author of this dissertation concentrates on such problems of the newly established modern Lithuanian state as the development of civic self-consciousness and formation of municipalities, i.e. building of the state 'from below'. She pursues the following tasks: to discover what kind of efforts (and how extensive) were made to prepare for local selfgovernment formation; to ascertain the evolution of functions and structure of local self-government institutions; to trace the way municipalities in the countryside, towns and districts were formed; to find both the internal and external obstacles to the formation of municipalities; to analyse systems of election to municipalities; to elucidate the development of relationships between local and central authorities; to assess the participation of ethnic minorities in the process of municipal formation; and to find out specific and most important fields of activity of the first municipalities.

The author comes to the conclusion that as various parties laid the foundations of the modern Lithuanian state, most attention was paid to the considerations of the state system rather than the status of local municipalities. She emphasises that throughout Lithuania municipal bodies were elected very soon and set to carry out their duties. Spontaneous participation by many people in the elections to the first municipalities testifies to their political consciousness.

Lina Balaišytė (Institute of Culture, Philosophy and Art Research, Vilnius Academy of Fine Arts). Dailininkas ir dailès užsakovas XVII a. - XVIII a. Vilniuje [Artists and their Patrons in Vilnius in the Second Half of the Seventeenth and the Eighteenth Centuries].

The research of this dissertation covers a group of approximately 150 secular artists - painters, sculptors and engravers - who lived and worked 
in Vilnius. The author defines as patrons certain bodies functioning within the city (the Church, magistrates, guilds, confraternities) or persons connected to artists via social or patronage institutions.

The researcher aimed to characterise the evolution of the artist's status in Lithuania through the analysis of the distinctiveness of artists' position in the community of Vilnius and the demand and regard of society for their work. She sought to discuss the features of the evolution of the artist's status; to overview the existence of various artist groups in Vilnius; to consider the social position of the artist in Vilnius; to analyse the nature and mechanism of artistic commissions; to discuss relations between the artists and their patrons; to examine the commissions made by town dwellers and the market for artworks.

The author came to the conclusion that for a long period of time skill and the perfect accomplishment were favoured more than education and creativity, but the profession of the artist came to be regarded higher in society in the second half of the eighteenth century. She stated that wide connections and high position of the artists mainly depended on their professional success. The artist usually maintained a direct relationship with his patron who frequently became the co-author of the artwork by suggesting the idea, which was expressed by artist.

Eglè Bendikaité (Vytautas Magnus University, Lithuanian Institute of History). Sionistinio judejimo ideja ir politika Lietuvoje 1906-1940 m. [The Ideas and Politics of the Zionist Movement in Lithuania in 19061940].

In her dissertation the researcher has drawn attention to the most important ideological and political aspects of the Zionist movement in the context of pre-modern Lithuania and the interwar Republic of Lithuania. The author aimed to depict the genesis of the Zionist movement and attempts to institutionalise it; to describe the organisational structure and ideological views of different trends and factions within the Zionist movement in Lithuania; to discuss the underlying areas of the activities of the Lithuanian Zionist organisation and their achievements; to trace the development of Zionist ideas and their influence on the Lithuanian Jewish community; to analyse the social basis for the support of Zionism in interwar Lithuania; and to reconstruct the relations between the Zionists and other Jewish and non-Jewish political groups and organisations.

The author established that Russian occupying authorities in Lithuania suspended the development of the institutionalisation of the movement. She also came to the conclusion that after long negotiations and delays the Vilnius Zionist group supported the formation of the modern Lithuanian state. In interwar Lithuania the Zionists became the most visible political group wishing to monopolise the positions among the Jews. 
Marius Sirutavičius (Vytautas Magnus University, Lithuanian Institute of History). Lietuvos Didžiosios Kunigaikštystès ir Maskvos valstybès santykiu diplomatinè kultūra (XV a. pabaigoje - XVI a. pirmojoje puseje). [Diplomatic Culture in the Practice of Relations Between the Grand Duchy of Lithuania and the State of Muscovy (between the end of the fifteenth century and the first half of the sixteenth century)].

The dissertation is about the diplomatic contacts and function mechanisms of the diplomatic system. The author seeks to find answers to such questions as what were the possible ways of action, how they were related to the values solidified in the diplomatic culture that preconditioned choices, rendered significance to their actions and controlled them. Among the tasks of research was identification of the values, norms and the code that were followed in the diplomatic practice of the two countries.

It was concluded that the main qualities of the representation system in the practices of the relations between the two states were determined by the special connection between the ruler and his diplomatic representative. The author established and described the regulation of the diplomatic representation related to the conception of honour, system of ranks and hierarchic relations. It established how the principle of diplomatic immunity was discussed, too. 